\title{
Europe and the impasse of centre-left politics in Turkey: lessons from the Greek experience
}

\section{Ziya Öniş \& Ioannis N. Grigoriadis}

To cite this article: Ziya Öniș \& loannis N. Grigoriadis (2010) Europe and the impasse of centreleft politics in Turkey: lessons from the Greek experience, Journal of Balkan and Near Eastern Studies, 12:3, 259-274, DOI: 10.1080/19448953.2010.506823

To link to this article: https://doi.org/10.1080/19448953.2010.506823

曲 Published online: 15 Sep 2010.

Submit your article to this journal 2

Џlll Article views: 147

Citing articles: 6 View citing articles $ک$ 


\title{
Europe and the impasse of centre-left politics in Turkey: lessons from the Greek experience
}

\author{
ZIYA ÖNIŞ and IOANNIS N. GRIGORIADIS
}

\section{Introduction}

This paper aims at exploring the state of centre-left politics in Greece and Turkey by focusing on the transformation of the two leading centre-left parties in the two countries, the Greek Panhellenic Socialist Movement (Panellinio Sosialistiko KinimaPASOK) and the Turkish Republican People's Party (Cumhuriyet Halk Partisi$\mathrm{CHP}$ ). Such a comparison is warranted for a number of reasons, despite size discrepancy and religious differences between the two countries. Both Greece and Turkey emerged from the Ottoman Empire and share to a considerable degree a legacy of top-down and crisis-ridden modernization. In both countries, a reformist and an underdog ${ }^{1}$ culture clashed, thus making modernization the product of the compromise between the two. In the case of Greece, PASOK has succeeded in ruling Greece for more than 20 years. While the party emerged in the 1970s with nationalist, anti-imperialist third-worldist elements, it was able to gradually move to the centre of the political spectrum in the mid-1990s and become a trigger of political reform. This process peaked during the Simitis administration, in which Greece regained its lost international prestige as 'the European country of the Balkans' and was able to fulfil the economic criteria for its membership in the Economic and Monetary Union (EMU). While still appealing to old slogans and rhetoric, the Simitis administration attempted to break old nationalist taboos on issues relating to Greek foreign and security policy. The early Simitis era became an ample example of how a centre-left party could form a greater winning social alliance, appeal to the winners of globalization and achieve high economic growth, while not compromising its social justice agenda. In the case of $\mathrm{CHP}$, the party increasingly distanced itself from its social democratic legacy. Failing to win political power, it was trapped into a defensive nationalist, anti-globalization and anti-reformist political agenda spearheaded by the question of secularism. The consolidation of Turkish democracy and the promotion of human and minority rights lost their significance, and the CHP emerged as Turkey's leading nationalist and anti-reform party, questioning the country's European vocation and tolerating military interventions into Turkish politics. The diminution of the CHP into a party of the 'secularist middle class' has deprived it of any chances to lead a winning social coalition and lead Turkey's political reform. This paper will seek conclusions on the future of centre-left politics in Turkey based on the Greek experience.

\footnotetext{
${ }^{1}$ Nikiforos Diamandouros, Cultural Dualism and Political Change in Post-Authoritarian Greece (Working Paper 1994/50), Instituto Juan March de Estudios e Investigaciones, Madrid, 1994.
} 


\section{Europeanization and the transformation of centre-left politics in Greece}

The experience of German-Italian-Bulgarian occupation and an ensuing bitter civil war shaped Cold War Greek domestic politics. Between 1946 and 1949 Greece suffered a bloody and destructive civil war between the state army and the communist insurgents who aspired to turn Greece into a socialist republic. The victory of the state forces in 1949 irrevocably positioned Greece in the Western camp and set the framework in which the Greek political system would operate in the following decades. The establishment of a pro-Western illiberal democratic regime by the civil war winners through the 1952 Constitution allowed for the persecution of communist intelligentsia, the polarization of Greek society and the marginalization of the Greek Left. The threat of communist subversion served as pretext for severe compromises in fundamental and political rights and the operation of para-state organizations operating beyond the rule of law. This trend was facilitated by the general Cold War climate in countries of Southern Europe. When social democratic or centrist parties rose to government, the military and bureaucratic establishment spearheaded by the Palace refused to surrender the full control of the country. The 1967 coup meant even harsher persecution of leftist political thought and interrupted the process of Greece's accession to the European Economic Community (EEC). After the fall of the junta in 1974, Greece's EEC accession became the primary task of the Karamanlis government. In this, however, Karamanlis was alone. Following a line reminiscent of postcolonial third-worldist states, Greek socialist and leftist parties-with the exception of the small KKE Esoterikou-fully objected to Greece's accession seeing such a development as a subordination of Greek sovereignty and national interests to Western European business interests. Andreas Papandreou, as an opposition leader, vehemently objected to the process and vowed to withdraw Greece from the EEC once elected. It was only after the rise of PASOK to power with the elections of 18 October 1981 that Papandreou abandoned his anti-EEC rhetoric and accepted the integration of Greece into the EEC. This did not mean that Greece immediately became a functional EEC member. Throughout the 1980s Greece was considered by many to be the bette noire of the Community. ${ }^{2}$

With the exception of the 1989-93 interlude, PASOK governments under Andreas Papandreou and Konstantinos Simitis led Greece's steps inside the European Union from 1981 to 2004. While many would argue that, due to Papandreou's populist policies, Greece lost a crucial chance in the 1980s to modernize its state and economy with EEC aid following the example of other poor member states such as Spain, Portugal and Ireland, Greece's democratic consolidation was secured through EEC membership. In his second administration from 1993 to 1995, Papandreou did show a more pro-European stance, although he was not able to follow the catalytic developments in Europe, the collapse of the Soviet Union, war in the Western Balkans and democratization in East Central Europe. Its relapse to an old-fashioned nationalist stance appeased the public opinion but had considerable consequences regarding Greece's international image and regional role. It was his successor Konstantinos Simitis

\footnotetext{
${ }^{2}$ George Pagoulatos, 'Believing in national exceptionalism: ideas and economic divergence in Southern Europe', West European Politics, 27(1), 2004, pp. 55-57.
} 
who assumed power in January 1996 that overcame the nationalist legacy of Andreas Papandreou and addressed Greek national interests through the acceleration of Greece's European integration.

A major crisis in Greek-Turkish relations over the sovereignty of the Imia/Kardak islets underlined the need for an urgent reconfiguration of Greek strategic objectives. Setting the target of membership in the EMU and Greece's membership in the 'hard core' of the European Union, Simitis turned Greek centre-left into the avant-garde of Greek EU federalism and put the ND, the party which had spearheaded the process in the mid-1970s, into an awkward position. He provided Greece with a new strategic vision called 'strong Greece' (ischyri Ellada) which projected the country as 'a European country of the Balkans and not as a Balkan country of Europe', a leader of the economic and political reform process in South-eastern Europe and an unyielding supporter of the European integration of all neighbouring states. Simitis argued that a 'strong Greece' could only be possible with a robust Greek economy. This required a radical departure from PASOK's distributionist legacy, fiscal discipline, control of inflation, structural reform including privatization, as well as introduction of the euro. In a speech at the Greek Parliament, Simitis outlined the main pillars of his policy as follows:

... Our equal participation in the process of European integration. This provides the means so our country can meet the challenge of globalisation, be competitive, support self-sustained development and improve living conditions.... The modernisation of the country, changes in the way our society operates to create more opportunities and capabilities for citizens ... to achieve more social justice and cohesion.... Our leading role in the Balkans. This is the way to offset our geographic isolation from the centres of the European Union.... And, finally, the defence of our national causes and rights....

The voice of the Greek government is prestigious and persuasive. We have proved that through hard, systematic and effective work, Greece can claim the position it deserves in Europe... We are no more the country of deficits, retrogression, of Hellenocentric isolationist self-reflection. We have proved that we are not a country which constantly asks for understanding for its special conditions and argues on the basis of its underdevelopment... ${ }^{3}$

This strategic vision comprised a radical departure from the third-worldist PASOK legacy of the 1970s and 1980s and brought the party much closer to the policy framework which characterized European social democratic parties in the aftermath of the cold war. ${ }^{4}$ Greek economic elites were assigned the task of leading regional economic integration by gaining key influence in the economies of Greece's economic hinterland. This new strategic role necessitated the acceleration and completion of Europeanization reforms within Greece which had been delayed for years due to their perceived domestic political cost. More significantly the government achieved the entrance of Greece into the Euro-zone in 1999 and contributed to a historic improvement of Greek-Turkish relations.

\footnotetext{
${ }^{3}$ Konstantinos Simitis, 'Speech to the Plenary Session of the Hellenic Parliament on the 1998 Budget', 21 December 1997, pp. 21-28.

${ }^{4}$ Michalis Spourdalakis and Chrisanthos Tassis, 'Party change in Greece and the vanguard role of Pasok', South European Society \& Politics, 11(3/4), 2006, pp. 503-504.
} 
Significant improvements in the legal protection of minority and immigrant rights were also to be noted. The infamous Article 19 of the Greek Citizenship Code which allowed for the stripping of minority members from their Greek citizenship was abolished. In the field of economic policy, a clear shift from previous PASOK policies was noted. Fiscal discipline was furthered and privatization gained pace. ${ }^{5}$ A rally in the Athens stock exchange was indicative of strong economic and social optimism. This marked a clear departure from older PASOK policies which prioritized statist economic policies over privatization and assimilation over minority and immigrant rights.

This is not to say that there were no shortcomings in the political performance of the Simitis administration. Its utter failure to implement the long-needed and planned reform of the social security system, ${ }^{6}$ accomplish the economic recovery and privatization of virtually bankrupt state-controlled companies such as Olympic Airways moderated the success of the Simitis government. The PASOK government proved unable to make hard but necessary decisions to deal with the needed structural reforms of the Greek economy. The social security reform was extensively discussed in the late 1990s, but the proposed reform measures were shelved as soon as they would meet fierce reaction from labour unions and public opinion including a large part of the electoral base of PASOK. Last but not least, corruption charges which became increasingly compelling in the late years of the Simitis administration reduced the popularity of PASOK and paved the ground for a wide ND victory in the 2004 elections. These outlined the limits of PASOK's transformation but should not obfuscate the major steps made which had a crucial effect on the Europeanization of Greek economic and foreign policy.

The centre-left maintained a dominant position in Greek politics from 1981 to 2004, and won power again in 2009. However, this became possible due to its responsiveness to the new international and domestic political circumstances. Despite its anti-Western, anti-imperialist rhetoric of the 1970s, PASOK was able to realize that the Greek national interest was full and effective participation in the EEC. In the 1990s, when Greece got entangled in a serious domestic political crisis and looked like a part of the Balkan problem rather than a part of its solution, it was PASOK again under the Simitis administration which failed to fall prey to nationalist and populist sirens and put forward Greece's full participation in the European EMU. This adaptability was a crucial element for the dominant position of the Greek centre-left and could be attributed to the foresight of its leaders. PASOK was able to increase its appeal to more educated and richer segments of Greek society. ${ }^{7}$

Leadership of the Greek centre-left was one of the main reasons for its successful transformations. Both Andreas Papandreou and Konstantinos Simitis were able to foresee the country's - and the party's - long-term interest and distance themselves from declared political promises which would forestall Greece's European integration. Despite the disappointment of a part of the PASOK's electoral base and membership, both leaders were able to further their pro-integration agenda.

\footnotetext{
${ }^{5}$ George Pagoulatos, 'The politics of privatisation: redrawing the public-private boundary', West European Politics, 28(2), 2005, pp. 371-376.

${ }^{6}$ Kevin Featherstone, Georgios Kazamias and Dimitris Papadimitriou, 'The limits of external empowerment: Greece, EMU and pension reform', Political Studies, 49(3), 2001, pp. 471-474.

7 Ilias Nicolacopoulos, 'Elections and voters, 1974-2004: old cleavages and new issues', West European Politics, 28(2), 2005, p. 277.
} 
This allowed the party to successfully adapt to the changes brought about by the end of the cold war, globalization and European integration. Dealing with the question of nationalism was also of paramount importance. In the early PASOK years, Andreas Papandreou had maintained a nationalist stance in all Greek foreign policy issues repeating that 'Greece belongs to the Greeks' and that national sovereignty and independence are foundation pillars of PASOK's policy. ${ }^{8}$ The Simitis administration distanced itself radically from that legacy. While still paying lip service to old slogans and rhetoric, the Simitis administration attempted to break old nationalist taboos on issues relating to Greek foreign and security policy. The rapprochement with Turkey had a central position in that respect. In the 1999 European Council summit in Helsinki, Greece lifted its objections to Turkey gaining EU candidate status, in return for setting a framework which could facilitate the resolution of both the Cyprus question and the bilateral Greek-Turkish disputes by 2004. This fundamental shift of Greek foreign policy regarding EU-Turkey relations was followed by a redefinition of Greek national interest. Greek national interest against neighbours was no more understood in zero-sum game terms. Greece aspired to assist the development, stability and European integration of its neighbours aiming to benefit from the fruits of that development as a key regional economic player, as well as from the 'peace dividend', the national resources which could be diverted from defence expenditures as a result of the resolution of longstanding conflicts.

\section{The peculiarities of centre-left politics in Turkey: the historical context}

The 1970s constitutes a useful starting point for a comparative analysis of the contrasting fortunes of centre-left politics in Greece and Turkey. The CHP reached the peak of its electoral success under the leadership of Bülent Ecevit in the elections of 1974. The CHP emerged as the dominant partner in the coalition governments of the late 1970s. Yet, this unusual success proved to be short-lived. The late 1970s was a highly unstable era in Turkish politics. A major economic and political crisis in the late 1970s peaked with the military coup of September 1980 which led to the exclusion of the CHP from Turkish politics. The 1970s also constitutes an interesting era in terms of highlighting the contrasting Europeanization experiences of the two countries, as well as similarities in the policies of PASOK and CHP. PASOK during this period was firmly against Greek membership of the European Community, which was identified with Western imperialist and capitalist interests. Yet unlike in the Greek case, CHP opposition exacted a toll on EEC-Turkey relations. In October 1978, the Ecevit government froze EEC-Turkey relations exactly at the time Greece was speeding up its efforts for full EEC membership. The 1980 coup dealt the strongest blow against EEC-Turkey relations and led to the suspension of the Europeanization process in Turkey.

The 1980s and the 1990s represented an era of increasing decline and marginalization of social democracy in Turkey. During this period, even though centre-left parties participated in different coalition governments at certain times, they progressively lost their electoral support, class alliances and linkages with

\footnotetext{
${ }^{8}$ Papandreou's January 1987 attempt to promote Greek-Turkey detente with Turgut Özal at Davos was only a short-lived exception which confirmed the rule.
} 
society. This process reached a climax with the 1999 parliamentary elections, in which the CHP failed to reach the 10 per cent electoral threshold and found itself outside the Parliament.

At the heart of the steady decline and marginalization of the CHP during the 1990s was the impact of the 1980 coup on Turkish social democracy. The closure of the established political parties of the pre-1980 era including the CHP by the interim military government and its anti-democratic and national security-based strategy to de-politicize society together have generated a negative impact on centre-left politics. Increasing splits within the centre-left have also contributed to the CHP's decline. Particularly striking in this context was the challenge posed by the emergence of the Democratic Left Party (Demokratik Sol Partisi-DSP) under the leadership of the CHP's previous leader, Bülent Ecevit, as a more nationalistically inclined alternative. This has constituted a major split on the centre-left axis of Turkish politics, resulting in the fragmentation of the social democratic vote. The reduction of social democratic politics into intra-party politics of the CHP and the failure of the party to respond effectively to strong societal demands for social justice and participation have caused both the growing detachment of Turkish social democracy from society and the increasing disenchantment of society towards the identity and ideology of the CHP. In this period, politics of the centre-left has been increasingly reduced to a contest over leadership and power politics within the party. ${ }^{9}$ Thus, in addition to the major splits in the centre-left during the 1980s and the 1990s, what we observe is a serious decline in the credibility and persuasiveness of the centre-left to present itself as a viable solution to the serious structural problems of Turkish society.

The post-1980 period has, in fact, given rise to a serious crisis of state-centrism; 'the legitimacy once enjoyed has been withdrawn in the eyes of the Turkish society at large, its democracy deficit has steadily increased, the national developmentalism has been seriously challenged and replaced by neo-liberal economic rationality ${ }^{\prime 10}$ Its secular national identity has been criticized and attacked by the resurgence of Islam. Its homogeneous vision of society has been challenged in ethnic terms by the rise of the Kurdish question. Its top-down mode of governing has been exposed to calls for democratization from civil society organizations and civil initiatives, and its uni-dimensional, security-based foreign policy has become inadequate in coping effectively with the increasingly complex and multidimensional international challenges. ${ }^{11}$

Since the 1980s and especially during the 1990s, both the changing international context, described as the processes of globalization, and radical transformations that have been occurring in Turkish society together have generated important challenges to the state-centric Turkish modernization, dismantling its very foundations and leading to its gradual demise. The changing nature of Turkish modernization and its ever increasing exposure to globalization constitute the historical basis for the decline of the CHP in terms

\footnotetext{
9 Ayşe Güneş-Ayata, 'The Republican People's Party', Turkish Studies, 3(1), 2002, pp. 102-121.

${ }^{10}$ Çağlar Keyder, 'Whither the project of modernity? Turkey in the 1990s', in Sibel Bozdoğan and Reşat Kasaba (eds), Rethinking Modernity and National Identity in Turkey, University of Washington Press, Seattle and London, 1997, pp. 37-51.

${ }^{11}$ Fuat Keyman, Türkiye ve Radikal Demokrasi, Alfa, İstanbul, 2001.
} 
of its social support, its ideological persuasiveness and its organic ties with society. ${ }^{12}$

Ironically, the CHP's failure to cross the threshold in the 1999 elections turned out to be a blessing-in-disguise as the party escaped scorn for the 2001 economic crisis, which severely hit Turkey's established political parties. In the November 2002 elections, the CHP could not match the electoral success of the Justice and Development Party, the AKP, a new centre-right party of Islamist origin, but nevertheless, became the only opposition party to enter the Parliament. ${ }^{13}$ In the postelection period, the fortunes of the two principal parties, the AKP and the CHP, diverged even further. In contrast to the proactive stance adopted by the ruling party, the AKP, on Turkey's key political issues such as relations with the European Union, the attitude of the CHP leadership appeared largely defensive and negative. Certainly, there was a false expectation on the part of key CHP figures that the AKP, given its Islamist heritage, would sooner or later find itself in confrontation with the state elites resulting in its ultimate closure as was the case with its predecessors the Welfare Party (Refah Partisi-RP) and the Virtue Party (Fazilet Partisi-FP). One could detect a failure here on the part of the CHP to recognize the adaptability and the learning process experienced by moderate Islamists in Turkey, as well the transformation of Turkish society since the 1980s.

In contrast to the very cosmopolitanism of the AKP, the CHP appeared to pursue a hyper-nationalist course. Regarding democratization, the party elites have tended to establish causality between democracy and secularism which resulted in recognizing the military as a necessary guardian of the state against possible violation of the principle of secularism. Whilst the commitment of the $\mathrm{CHP}$ to secularism was well-founded, its strict or hard-line interpretation of secularism hardly left any avenue for democratic opening in the direction of extending the realm of politics for religious freedoms. In CHP's view, democracy was conditioned by secularism and not vice versa. The party missed an important opportunity to present a major challenge to the ruling party by prioritizing a narrow understanding of secularism over democracy.

Hence, the dominant vision of the CHP in the public mind and in key international circles was that of a defensive, inward-looking party that lacked the kind of democratic and reformist credentials to tackle Turkey's serious economic and political challenges. Ironically, the conservative position adopted by the CHP on key domestic and foreign policy issues resulted in its legitimacy problem. This, in turn, has helped to increase the AKP's societal and international support leading to the aggravation of the asymmetry in the electoral fortunes of the two parties. Moreover, what was also striking was the lack of concern on the part of the $\mathrm{CHP}$ with the economic domain, centring its attention instead entirely on cultural, political and security-related issues with a heavy focus on secularism and the Cyprus issues. With respect to these two central issues, the position adopted by the party was quite unconstructive and clearly failed to take into account the changing public opinion. On the Cyprus issue, for example, the party's position opposed a compromise solution at any cost. Nevertheless its notions of national interest,

\footnotetext{
${ }^{12}$ Fuat Keyman and Ziya Öniş, 'Globalization and social democracy in the European periphery: paradoxes of the Turkish experience', Globalizations, 4(2), 2007, pp. 211-228.

13 Ziya Öniş and E. F. Keyman, 'Turkey at the polls: a new path emerges', Journal of Democracy, 14(2), 2003.
} 
sovereignty and security appeared to be seriously outdated. Indeed, there was no attempt to take into account changing public opinion on this issue, notably the outcome of the elections in northern Cyprus itself that clearly signalled popular demands in the direction of an internationally acceptable solution. It was also interesting that as a social democratic alternative, the party failed to place key issues such as the performance of local government and the need to fight endemic corruption as its central priorities. The outcome of these strategic errors was to marginalize the $\mathrm{CHP}$ even further in the electoral process both in the municipal elections of 2004 and the general election of 2007. ${ }^{14}$

\section{Explaining the current impasse of social democratic politics in Turkey: the problem of path dependence and the role of agency}

The current impasse of social democracy in Turkey is a multi-dimensional phenomenon and the collective outcome of several influences. Certainly, the current stance of the CHP reflects the legacies of the single party era of the interwar period. The CHP of the early Kemalist era was closely associated with a certain type of top-down, state-centric modernization based on a particular understanding of 'secularism' and 'national identity'. ${ }^{15}$ This historical association with the Kemalist modernization project has had the unfortunate repercussion of making it rather insensitive to demands for recognition on the basis of religious or ethnic identity. Indeed, the party leadership increasingly conceived of its mission as stabilizing or protecting the basic founding principles of the Turkish Republic at all cost. Regime stabilization as opposed to electoral success under a normal parliamentary democratic regime emerged as the overriding concern for the party leadership, particularly as the general elections of 2007 approached. The emphasis placed on regime stability also had a parallel influence in terms of contributing to growing Euro-scepticism in spite of the fact that the party has historically associated with the goal of Westernization-a natural corollary of which is EU membership. The CHP of the recent era has increasingly been characterized by its 'defensive nationalism' which has made it heavily sceptical of EU conditionality on the grounds that some of the key EU-sponsored reforms would undermine the unity and secular character of the Turkish state and contribute towards a dual process of partition of the Turkish state and Islamization of Turkish society.

An increasing requirement of electoral success in democratic regimes is that political parties of centre-left or of centre-right origin need to extend their horizons beyond class-based politics and appeal to a wide range of interests in order to obtain a large share of the popular vote. Class-based politics or appealing to certain specific segments of society is simply not a good strategy if a political party is at all interested in building successful electoral coalitions.

Historically, the CHP has been rather ineffective in its attempts to build broad, cross-class coalitions. Only in the 1970s, under the premiership of Bülent Ecevit, did the CHP actually manage to achieve major success in terms of building broad-based societal support. In the Turkish context, conservative parties of the

\footnotetext{
${ }^{14}$ Sinan Ciddi, 'The Republican People's Party and the 2007 General Elections: the politics of perpetual decline?', Turkish Studies, 9(3), 2008, pp. 437-455.

${ }^{15}$ Bozdoğan and Kasaba (eds), Rethinking Modernity, op. cit.
} 
centre-right have been much more prosperous in this respect as the successive experiences of the Democratic Party led by Menderes in the 1950s, the Justice Party (Adalet Partisi-AP) led by Süleyman Demirel in the late 1960s and the early 1970s, the Motherland Party (Anavatan Partisi-ANAP) led by Turgut Özal in the 1980s and, finally, the AKP under Recep Tayyip Erdoğan clearly testify. Centreright parties effectively managed to appeal to both religious and nationalist sentiments of society at large. They have also managed to make business, both large and small, an integral component of a broad-based electoral coalition. The $\mathrm{CHP}$, in contrast, has had limited success even in terms of its attempts to bring small- and medium-sized business interests into the party's electoral coalition. All these factors have sustained an image of an elitist party, a party of bureaucrats and intellectuals, rather detached from society at large.

Yet another structural influence concerns the nature of the welfare state and the nature of organized labour in Turkey. Unlike its Western European counterparts, the welfare state has been underdeveloped in the Turkish context and unionized labour has constituted a small element of the overall workforce. A significant proportion of the population has been located in rural areas and employed in agricultural activities. All these factors have placed centre-left parties in a disadvantageous position in the Turkish context. In any case, labour unions, which reached the peak of their influence in the 1970s, have been increasingly weakened and marginalized during the post-1980 era of neo-liberal globalization. This, in turn, made the job of an allegedly centre-left party even more difficult. Admittedly, the labour unions have also been on the defensive in Western European democracies during the neo-liberal period. Yet, they continued to be far more influential than has been the case in the Turkish context.

Military coups in Turkey, notably the coup of 1980, have also had a devastating impact in terms of fragmenting and de-institutionalizing the Turkish party system. Arguably, the effects of the 1980 coup on centre-left politics have been more profound compared to its effects on the centre-right. All the major political parties of the pre-1980 era, namely, the AP, the CHP, and the National Salvation Party (Milli Selamet Partisi-MSP) were closed down following the military coup of September 1980. Furthermore, the leaders of these parties Süleyman Demirel, Bülent Ecevit and Necmettin Erbakan were banned from participating in active politics for the course of the next decade. This has clearly had the effect of a major rupture or discontinuity in terms of its impact of the institutional evolution and the maturation of the Turkish party system. Yet, the centre-right certainly proved to be far more adaptable with Turgut Özal's ANAP, a natural successor to the AP of the earlier era, emerging as the leading party in the November elections of 1983, following the end of the military interlude and the return to democracy. Centre-left politics was among the prime targets of the military intervention and the ensuing authoritarian Constitution of 1982 provided restricted space for left-wing politics, not only by its vigorous repression in the party political realm but also through the repression of leftist intellectuals and restrictions placed over the activities of organized labour. Centre-left politics in Turkey has been clearly on the defensive during the course of the 1980s and the 1990s. Several parties have emerged which describe themselves as centre-left or social democratic, including the leader-dominated party of Bülent Ecevit's DSP and the Social Democratic Populist Party (Sosyaldemokrat Halk Partisi-SHP) led by Erdal İnönü. Both of these parties 
managed to become partners in coalition governments at different times, the former between 1999 and 2002 and the latter during the early 1990s. But these different manifestations of centre-left politics were able to obtain only around 20 per cent of the total vote and have clearly failed to replicate the electoral success of the CHP in the 1970s. Indeed, the CHP itself could only emerge under its conventional name in the mid-1990s, and once again become an important force in Turkish politics as the principal opposition party as recently as 2002 .

Structural explanations and the problem of path-dependence are important but can only provide part of the explanation. A complete explanation also needs to take sufficient account of the role of agency and more specifically the role of leadership. The CHP leadership, in stark contrast to its Greek counterpart, PASOK, failed to break away from the domestic historical legacies and take advantage of the opportunities provided by the global and regional structural context. In the post-2002 context, attempts to move the party in a more cosmopolitan reformist direction by opposition groups led by Kemal Derviş and his associates were marginalized. The attempt of İsmail Cem, a former Foreign Minister and senior member of the DSP to form a reformist centre-left party, the New Turkey Party (YTP) failed to change Turkey's political map. The party had a dismal performance in the November 2002 elections, collecting only 1.2 per cent of the vote. Soon after, the party was dissolved, and Cem joined the ranks of the CHP. The tight organizational structure of the party and absence of intra-party democracy facilitated this marginalization process and contributed to the extraordinary dominance of the party leader, Deniz Baykal, in the process. To the surprise of many both at home and abroad, the leadership of the AKP proved to be much more flexible and adaptable in its response to the opportunity space provided by the changing domestic, regional and global context.

Turning our attention to the global context, there is no doubt that the process of world-wide neo-liberal restructuring from the early 1980s onwards has left social democratic parties in a difficult position. The possibilities for sustaining the welfare state in its existing form ceased to be a viable alternative even in advanced industrialized countries of Europe. Nevertheless, neo-liberal globalization also helped to create a sizable group of 'winners' which could be effectively incorporated into the broad electoral coalition of a centre-left party. The experiences of 'third way' style political parties in Europe such as New Labour under Tony Blair and SPD under Gerhard Schröder demonstrated that social democrats could achieve significant electoral success. ${ }^{16}$ The key for this was the modification of their strategies which involved an attempt to come to terms with market-friendly strategies and the reform, redefinition and decentralization of the welfare state and new thinking based on a broader understanding of inequality incorporating its 'material redistribution' and 'recognition' dimensions. The prospect of EU membership and the associated set of democratization reforms provided a major opportunity space for a European third way-style social democratic party in Turkey from the late 1990s onwards. The crisis of Turkish modernity and the rising demands for recognition based on Islamic or Kurdish identity as well as the growing strength of the civil society helped to extend this opportunity space. Yet, ironically it was the AKP, a

\footnotetext{
${ }^{16}$ On this, see Donald Sassoon (ed.), Looking Left: European Socialism after the Cold War, I. B. Tauris, London, 1997.
} 
centre-right party of Islamist origin and not the CHP which has effectively capitalized on this new opportunity space.

\section{CHP versus PASOK: the principal contrasts}

Shifting attitudes regarding modernization comprise an interesting point of contrast between PASOK and the CHP. According to Diamandouros, Greek modernization came about as a result of a clash between a reformist and an underdog culture. ${ }^{17}$ Western-inspired and willing to break away with tradition, the reformist culture had been represented by secular urban elites throughout the 19 th century and found in the early 20th century its best representative in Eleftherios Venizelos. This culture was countered by a culture characterized by a vigorous belief in redistributionist policies, national exceptionalism, prioritization of a narrowly defined national interest and a conspiracy-driven understanding of international politics. This 'underdog' culture strongly resonated with dominant public opinion views in the 1970s and shaped PASOK's worldview and political programme. Yet in the course of 20 years, PASOK underwent such a transformation that by the late 1990s it became the staunchest representative of the reformist culture in the Greek context. In the case of Turkey, a similar division could be observed in the early years of Atatürk's reform. The CHP was the reform party par excellence, aiming to implement Atatürk's Westernization programme and sever Turkey's links with its Ottoman and Islamic past. In Turkey the 'underdog' culture was represented by forces which opposed Turkey's Westernization underlining its non-Western identity. This culture was best represented in the 'Just Order (Adil Düzen)' political programme of the historic leader of Turkish political Islam Necmettin Erbakan. Yet following the deep socioeconomic changes which Turkey underwent in the 1980s, a reverse process was observed. While a majority current within Turkish political Islam was able to shift from the underdog to the reformist camp, the CHP moved to the reverse direction. It came to represent those elements of Turkey's secularist elite which failed to adapt to the new environment defined by globalization and Turkey's steps towards European integration. The culmination of Turkey's Westernization process, namely, its EU membership, was seen with outright suspicion, as democratic consolidation also meant the end of tutelary privileges enjoyed by the country's secularist elite. Increasing emphasis on a narrow definition of national interest and defence of the status quo even at the expense of human rights and social peace did not allude to a social democratic party but rather reminded of the interwar authoritarian statist legacy of the CHP. Thus the CHP ended up appropriating a statist, pro-status-quo version of the underdog culture.

At the risk of oversimplifying, perhaps the most striking difference between the political parties is that PASOK stands as a 'party of government' whereas the $\mathrm{CHP}$ can be described as the 'party of the state'. PASOK has been in office for a period of more than 20 years and is used to be a natural candidate for office. In contrast, the history of the CHP is characterized by two dramatically different phases. During the single party era, the CHP was the political arm of the Kemalist ruling elite and, hence, the natural party of government.

\footnotetext{
${ }^{17}$ Diamandouros, op. cit.
} 
Once the transition to multi-party democracy was accomplished in 1950, the role of the party changed to the position of a quasi-permanent opposition party in a political environment dominated by parties on the centre-right of the political spectrum. It was only in the mid-1970s under the leadership of Bülent Ecevit could the CHP mobilize itself in such a way as to win a large share of the total vote and emerge as the leading party in the country. Even then, however, the votes generated were not enough to generate a majority in the Parliament. The CHP found itself in a difficult position of forming a coalition with right-wing parties. Indeed, the period during which the CHP has managed to emerge as a serious contender for political power proved to be short-lived. The economic crisis of the late 1970s and the subsequent military coup of September 1980 embodied disastrous consequences not only for the party itself, but for the social democratic movement in Turkey in general. Arguably, this strange mix of being the natural party of government during a critical phase of Turkish modernization followed by a new role of a quasi-permanent opposition party for most of the post-war era has left a deep imprint on the mind-set of the party leadership which perhaps explains the attitudes of Baykal and his associates during the most recent era.

\section{Lessons of the Greek experience for the Turkish context and the limits of comparative analysis}

One of the major lessons of the PASOK experience has been that shifting from distributionist definitions of social justice may indeed not have punitive electoral effects. In fact, it may form the basis of a wider political alliance including the political centre, if it entails a more comprehensive definition of social justice. Social justice was not understood as simply distribution of benefits to the weaker parts of the society or to the party clientele, but was directly linked with policies aiming to promote economic growth and competitiveness, which would allow the implementation of social policy based on created surplus and not debt. This means that a social democratic party need no more be a party of the weak but a party of those who aim to achieve harmonious social and economic development and further social policies, which would not undermine policies aiming to achieve fiscal stability and economic growth. In the case of Greece, improvement of the country's economic performance was achieved alongside the acceleration of a privatization programme and increasing integration to global economy.

Moreover, centre-left parties do not need to totally disengage from nationalism, but can contribute to new definitions of national interest, more compatible with globalization and European integration. Redefining national interest in light of the new political conditions set by the end of the cold war, Greece's participation in the European Union and the need to promote Europeanization in the Balkans allowed PASOK to divert Greek nationalism from long-standing regional disputes to the vision of a new 'strong Greece', willing to share its political stability and economic prosperity with its neighbours and base its leading regional role on these. Greek national interest was understood in 'win-win' terms with the country's neighbours. This facilitated efforts for the resolution of long-standing disputes. 
The profound transformation of PASOK notably during the course of the 1990s contains some interesting implications for the current Turkish experience. The first lesson is that the ongoing Europeanization process constitutes a powerful dynamic force which also helps to transform a heavily nationalistic, inward-oriented and defensive social democratic movement to a more globalization-friendly, Western European style social democratic movement over time. Hence, the current state of the CHP does not necessarily represent a long-term, sustainable equilibrium position. At the same time, however, change is a slow and highly painful process, and the PASOK experience is quite striking in this respect in the sense that resistance has continued, even though Greece joined the European Community at a relatively early stage in 1981 . The second major lesson is that structural factors alone are unable to account for this change. Leadership matters. It was the critical leadership of Simitis which was instrumental in the transformation of Greek social democracy which, in turn, played an extremely critical and constructive role in the adaptation of the Greek economy and political system to European norms in the late 1990s. This suggests that Turkey may also experience a similar phase in the future where a leadership change in the CHP could play a significant transformative role. The third broad lesson is that social democracy contributed to the European transformation process of Greece and at the same it has also been transformed itself as part of the ongoing Europeanization dynamic. This implies that social democracy becomes both a subject and object of democratization. Clearly, these broad lessons create a certain bias towards optimism concerning the future trajectories of social democracy and the Europeanization process in Turkey.

At the same time, however, one ought to be aware of the fact that there are certain limits to the possible lessons one could draw from the Greek experience for the Turkish context. Social democracy in Greece has been able to capitalize on the fact that Greece has historically a much more cohesive social structure than Turkey. Greece's defeat in the 1919-22 Greek-Turkish war led to territorial losses and a population exchange which left it smaller but very homogeneous. Cleavages in Turkey along the lines of ethnic and religious identity in the Turkish context have remained far more pronounced. These cleavages, in turn render the task of any social democratic party in Turkey far more problematic than is the case in Greece. Despite the key role of the Orthodox Church in Greek political life, secularization and the role of religion in the Greek public sphere have not comprised ground for contestation as in the case of Turkey. Similarly, the minority problem in the Turkish context, notably but not exclusively in relation to the identity claims of the sizeable Kurdish minority in Turkish society, has no direct counterpart in the Greek context. Immigration into Greece and the associated problem of integrating minorities into the main fabric of Greek society has emerged as an important social and political problem since the end of the Cold War. Yet, the problem is clearly not comparable in terms of its scale and intensity to the problem of integrating minorities and notably the Kurdish minority in the Turkish context.

Yet another issue that makes a comparison between PASOK and CHP somewhat problematic concerns the differences in the Europeanization experiences of the two countries. The fact that Greece attained Community at a relatively early stage in 1981 provided an environment to the transformation of centre-left politics in Greece. In Turkey, the Europeanization process and the 
question of EU membership has remained a hotly contested issue. Furthermore, Turkey's European identity continues to be a matter of intense debate in public deliberations as is clearly evident from the recent constitutional debate and its poor results. The decision to include or exclude Turkey is part and parcel of a parallel debate on the future course of the European integration project itself. Clearly such debates have negative repercussions in Turkey itself contributing to the process whereby anti-EU and anti-reform elements gain an upper hand, and pro-EU and pro-reform elements finding themselves very much on the defensive. Indeed, following a Golden Age period of 2002-2005, the Europeanization process in Turkey appears to be at a stalemate and this provides a rather unattractive milieu for the kind of transformation of $\mathrm{CHP}$ along the lines of a European style social democratic party replicating the past experience of PASOK in the process. Parallel to the relative weakness of the Europeanization process, the fact that democracy is still far from being fully consolidated and the continuing importance of the military in Turkish politics represent major hurdles on the path of social democratic transformation in the Turkish context.

Added to the comparative weakness of the momentum and depth of the Europeanization process in the Turkish context, the current European and global context also provide a less favourable environment for the transformation of social democratic politics in Turkey. Third way-style European social democratic parties in Europe have been very much on the defensive in recent years and have been losing the electoral stronghold which they had managed to establish across Western Europe in the late 1990s. The parties in question have been experiencing a structural problem in the sense that constructing electoral coalitions which include both winners and losers of the globalization have become progressively more difficult. In an environment of rising unemployment and fears of immigration, social democratic parties faced growing competition from far-left as well as right-wing populist parties, as the recent German experience clearly testifies with the SPD being forced into a coalition with Christian Democrats. Similar structural problems have manifested themselves in the Greek context and have led to the breakdown of the electoral dominance of PASOK since 2004. In the early years of George Papandreou's administration, PASOK proved unable to defend Simitis' legacy and suffered severe electoral losses both to its left and right. This was underlined in the September 2007 parliamentary elections, when the ND scored an easy victory by collecting 41.83 per cent, while PASOK collected only 38.1 per cent, almost 2.5 per cent less than in the 2004 elections. PASOK's electoral fortunes changed dramatically in the early elections of October 2009, when it scored a historic victory collecting 43.98 per cent of the vote, more than 10 per cent than the ND. Yet its success was rather a function of the failure of the ND administration than the appeal of its own political programme. The current global economic crisis will make the job of any social democratic party especially in terms of pursuing a redistribution-based social policy agenda exceedingly difficult. Even if such parties manage to win elections as a reaction to the failures of the incumbent parties, the scope for success will be considerably restricted compared to the much more favourable global liquidity environment which ruled during the early part of the decade. All these considerations suggest that the PASOK-style transformation of the CHP could be a much more painful and lengthy process, given the constraints imposed by the current European and international context. 


\section{Concluding observations: looking towards the future}

The comparison of PASOK and CHP can provide useful conclusions for the reform steps which could bring the Turkish centre-left to the front stage of Turkish politics. To be successful social democratic parties need to become responsive to political and economic developments and readjust their strategies. On the economic side, finding solutions on how to achieve higher rates of economic growth and fairly distribute the national income is the true crux of centre-left politics today. Widening the political agenda, increasing electoral appeal beyond disenfranchised political groups towards the political centre and expanding their political programme beyond redistribution issues to address economic development and growth are some useful implications of the policy. Solid commitment to democratic values and embracing immigrants and minorities, which form a substantial part of the disenfranchised in contemporary Western societies, is also imperative. Adopting a more tolerant approach towards diverse cultures not only befits social democratic ideals but also proves to be a smart political strategy. This can assure the leading role of social democratic parties in the changing conditions of European politics.

In particular, the experience of PASOK is a telling example of how social democratic parties in the era of globalization can display resilience to change and display unusual adaptive capacity to changing environments at the same time. PASOK's transformation under Simitis involved a new understanding of the national which was much more in tune with globalization. The new and transformed PASOK displayed a stout commitment to democratic values and a more multicultural approach based on a novel understanding of the weak and the poor which included minorities and immigrants. The PASOK experience also clearly highlights the fact that an effective social agenda continues to be an integral element of contemporary social democracy. Yet, social agenda cannot simply be reduced to class-based redistribution from capital to labour. The recognition element also constitutes a key element of a broader understanding of redistribution. The PASOK experience also highlights how a social democratic party was both transformed by the ongoing Europeanization process and also became a leading contributor to the deepening of the Europeanization process. These observations could generate a certain degree of optimism concerning the current impasse of centre-left politics in Turkey and suggest that the present stalemate does not necessarily represent a permanent or sustainable equilibrium.

Turning to the Turkish context, the CHP of the post-2002 era is rather reminiscent of PASOK in the late 1970s, whereas it was the ruling party, the AKP, which despite its strong conservative roots, displayed the kind of adaptability to changing domestic and external conditions, displaying significant parallels with the transformed PASOK of the 1990s. Engagement and dialogue are much better recipes for overcoming the current polarized state of Turkish politics and Turkish society. At a time when the AKP has lost much of its reformist dynamism and its steadfast pro-European orientation, the CHP could still go through a PASOK-line transformation over time and establish itself as a major force in Turkey's revitalized Europeanization process. The obstacles on the path of such transformation, both domestic and external, are quite formidable and change, if it ever takes place, will be a lengthy and protracted process. 
Ziya Öniş is Professor of International Political Economy at Koç University in Istanbul. Until recently he was the Director of the Graduate School of Social Sciences and Humanities at Koç University. He was previously a Professor of Economics and International Affairs at Boğaziçi University, Istanbul. His most recent publications include (with C. Bakır) 'The Regulatory State and Turkish Banking Reforms in the Age of Post-Washington Consensus', Development and Change, 41(1), 2010, pp. 77-106; Turkey and the Global Economy (Routledge, London, 2009) (co-edited with F. Şenses); 'Beyond the 2001 Financial Crisis: The Political Economy of the New Phase of Neo-liberal Restructuring in Turkey', Review of International Political Economy, 16(3), 2009, pp. 409-432; 'Conservative Globalism at the Crossroads: The Justice and Development Party and the Thorny Path to Democratization in Turkey', Mediterranean Politics, 14(1), 2009, pp. 21-40; 'Between Europeanization and Euro-asianism: Foreign Policy Activism in Turkey during the AKP Era', Turkish Studies, 10(1), 2009, pp. 7-24 (with Ş. Y1lmaz).

Address for correspondence: Department of International Relations, College of Administrative Sciences \& Economics, Koç University, Rumelifeneri Yolu Sariyer, Istanbul TR-34450, Turkey. E-mail: zonis@ku.edu.tr

Dr Ioannis N. Grigoriadis is Assistant Professor at the Department of Political Science, Bilkent University. Between 2004 and 2009 he taught at Sabanci University, Isik University and the University of Athens. His research interests include European, Middle Eastern and energy politics, nationalism and democratization. His recent publications include Trials of Europeanization: Turkish Political Culture and the European Union (Palgrave Macmillan, London and New York, 2009); 'Friends No More?: The Rise of Anti-American Nationalism in Turkey', Middle East Journal, 64(1), Winter 2010, pp. 51-66; 'Islam and Democratization in Turkey: Secularism and Trust in a Divided Society', Democratization, 16(6), December 2009, pp. 1194-1213; and 'The Orthodox Church and Greek-Turkish Relations: Religion as Source of Rivalry or Conciliation?', in Jeffrey Haynes (ed.), Religion and Politics in Europe, the Middle East and North Africa (Routledge, London, 2009), pp. 51-70.

Address for correspondence: Department of Political Science, Bilkent University, Bilkent, Ankara TR-06800, Turkey. E-mail: ioannis@bilkent.edu.tr 